\title{
5. Skogens hevn - Ibsens Vildanden i naturlig belysning
}

\section{Mads B. Claudi}

Sammendrag Artikkelen presenterer en økokritisk lesning av Henrik Ibsens Vildanden, hvor stykket forstås som en refleksjon over det moderne menneskets objektiverende syn på sin omverden. Idet symbolet erstattes av synekdoken som lesningens sentrale begrep, åpnes en fortolkning som ser skogen, loftet og ikke minst villanden som synekdokiske representanter for en natur som er skadd av menneskelig virksomhet, og som hevner seg på menneskene, slik Ekdals profetiske replikk i andre akt signaliserer: «Der er hævn i Skogen.»

Nøkkelord Henrik Ibsen I Vildanden | økokritikk | synekdoke | litteraturdidaktikk

\begin{abstract}
The article presents an ecocritical reading of Henrik Ibsen's The Wild Duck, seeing the play as a reflection upon modern man's objectivizing view of his environment. Replacing symbol with synecdoche as the reading's central term allows for an interpretation that sees the forest, the loft, and indeed the wild duck itself as synecdochical representatives of a nature harmed by human activities, and revenging itself upon man, as indicated by Ekdal's second act prophecy: «The forests avenge themselves.»
\end{abstract}

Keywords Henrik Ibsen I The Wild Duck I ecocriticism I synecdoche I literature pedagogy

22. juni 1863 vedtok Stortinget en lov kalt Lov om Skovvæsenet. Den skulle sette en stopper for en pågående rovdrift på norsk skog, ikke minst ved å begrense hogsten i statsallmenningene, altså på statlig eid grunn, og den innførte blant annet et forbud mot å selge ut allmenningsareal til private. Problemet med for sterk utnytting av skogen var ikke nytt; siden 1848 hadde det vært gjort ulike juridiske forsøk på å beskytte skogene ved å begrense skogsdriften (NOU 2018: 11, s. 41f). Skog- 
bruk og trelast var big - og stadig bigger - business i 1800-tallets Norge, så stor at virksomheten her gjennom det meste av århundret var landets enten største eller nest største eksportindustri (Hodne \& Grytten 2000, s. 106). På slutten av 1800-tallet sørget den for over 40 prosent av de samlede norske eksportinntektene. ${ }^{1}$ «Den nye sagbruksindustrien ble en motor i den sterke industrikapitalistiske modernisering de neste tiår», skriver Rune Slagstad med henvisning til tiårene etter at Lov om Skovvæsenet ble vedtatt (Slagstad 2001, s. 73). Og loven virket ikke bedre enn at skogene var «nokså utarma» tidlig på 1900-tallet, som det heter i en SSB-rapport. $^{2}$ Da hadde trelasthandelen vært med på å gjøre Norge til et av Europas rikeste land. ${ }^{3}$

Henrik Ibsen vokste opp i en by hvor trelasthandel og -eksport var en viktig næringskilde. Kanskje registrerte han oppsvinget i næringen som fulgte etter at Storbritannia begynte å redusere importtollen på trelast i 1842. Han kan neppe ha unngått å legge merke til pengene som etter hvert strømmet inn til norske trelasthandlere i de store utskipingshavnene i Christiania, Drammen, Moss, Fredrikstad og Skien. Kan hende fikk han også med seg diskusjonene om skogsdriftens konsekvenser og de ulike forsøkene på å regulere hogsten i de norske skogene (jf. NOU 2018: 11, s. 41f). ${ }^{4}$ Han gikk i hvert fall neppe glipp av at Jonas Lie, hans venn fra studenttiden på Heltberg Gymnas, i 1868 gikk dundrende konkurs og pådro seg stor gjeld etter å ha mislyktes med spekulasjon i skog, en erfaring som danner grunnlaget for hans roman En Malstrøm fra 1884. Den nyutkomne romanen er omtalt i et brev fra Ibsen til Lie den 20. november samme år, den samme måneden som den utkom, og ni dager etter at hans egen Vildanden dukket opp i hyllene hos bokhandlerne i København og Kristiania.

Kanskje tok Ibsen også notis av Stortingets lovvedtak fra 1863. Sikkert er det i hvert fall at problematikken med skogspekulasjon og med skogsdrift i statens allmenninger finner veien nettopp til Vildanden, der den utgjør selve kilden til de sentrale begivenhetene. Se bare:

1 https://www.ssb.no/jord-skog-jakt-og-fiskeri/artikler-og-publikasjoner/nye-tider-for-skogeigaren, lest 7. januar 2020. Til sammenligning har de samlede inntektene fra norsk eksport av olje og gass utgjort mellom 47 og $61 \%$ av Norges totale vareeksport i perioden 2000-2018. For 1990-årene varierte andelen mellom 39 og 49 \% (https://www.norskpetroleum.no/produksjonog-eksport/eksport-av-olje-og-gass/, lest 7. januar 2020).

2 https://www.ssb.no/jord-skog-jakt-og-fiskeri/artikler-og-publikasjoner/nye-tider-for-skogeigaren, lest 7. januar 2020.

3 https://www.norgeshistorie.no/industrialisering-og-demokrati/teknologi-og-okonomi/1504norge-blir-et-industriland.html, lest 7. januar 2020.

4 Jf. https://www.regjeringen.no/no/dokumenter/nou-2018-11/id2605120/sec3, lest 7. januar 2020. 


\section{GREGERS:}

Han og du var dog begge sammen om det store skogkøb -

\section{WERLE:}

Men var det ikke Ekdal, som optog kortet over strækningerne, - dette uefterrettelige kort? Ham var det, som drev al den ulovlige hugst på statens grund. Det var jo ham, som stod for hele driften deroppe. Jeg havde ikke rede på, hvad løjtnant Ekdal foretog sig (s. 37). ${ }^{5}$

Dette er fra dialogen mellom grosserer Werle og Gregers i første akt. Werles forhenværende kompanjong Ekdal har gjort - eller har i hvert fall blitt kjent skyldig i å ha gjort - akkurat det som loven av 1863 skulle forhindre. Selskapet deres har kjøpt opp statlig skog og drevet hogst på statens eiendom. Dermed har det bidratt til det som var et presserende økologisk problem i Ibsens samtid, nemlig utarming av skogene. Det er altså et stykke miljøkriminalitet som er utgangspunktet for hele stykkets intrige: Det er det som sørger for løytnant Ekdals fall, og som setter Werle i et slags skyldforhold til Ekdal-familien. Og det er dette skyldforholdet som gjør det mulig for ham å i gåseøyne hjelpe Hjalmar, og på den måten sørge for at Hjalmar kommer sammen med Gina og overtar farsrollen for Hedvig, en hjelp det i sin tur blir Gregers’ prosjekt å avsløre. På denne måten er et økologisk problem lagt mellom linjene i Vildanden, og noen ganger også på dem. Werle og Ekdal har drevet en for intensiv kommersiell utnyttelse av en av det norske 1800tallssamfunnets aller viktigste naturressurser. Selve begrepet er anakronistisk anvendt på Ibsens drama, men det er likevel nærliggende å hevde at alle de sentrale konfliktene i stykket springer ut av en naturutnyttelse som ikke er bærekraftig. I fortsettelsen skal jeg forfølge det jeg mener er en grønn tråd gjennom Ibsens drama, og peke på det som i mine øyne er en vesentlig og hittil oversett side ved stykket. Samtidig, og mer generelt, håper jeg å kunne eksemplifisere hvordan læreplanens bærekrafttema kan virkeliggjøres som lesemåte, også i møte med tekster som ikke ved første øyekast setter naturen eller menneskets forhold til den i forgrunnen.

5 Alle sitater og sidetallshenvisninger refererer til verksutgaven som foreligger i Henrik Ibsens skrifter (2009). 


\section{NATUREN SOM SUBJEKT ELLER OBJEKT? TO NATURSYN}

Naturovergrepet som kompanjongene Ekdal og Werle har begått, kaster skygger over hele dramaet, fra begynnelse til slutt. Det introduseres allerede i tredje scene, der tjenerne snakker om gamle Ekdal og hans fall. «[H]an har såmænd vær’t en fin fyr i sin tid, gamle Ekdal», sier Pettersen til Jensen: «Men så slog han sig nok på skoghandel eller hvad det var. De siger, at han skal ha' gjort grossereren et fælt stygt puds engang» (s. 13f). Ikke lenge etter tas temaet opp i den omtalte samtalen mellom Gregers og Håken Werle, før vi møter det igjen i andre akt, i dialogen mellom Gregers og Ekdal. Der får vi for første gang også innblikk i hvordan Ekdal ser på saken:

EKDAL

[...] For skogen, ser De, - skogen, skogen -! (drikker) Står skogen bra' deroppe nu?

\section{GREGERS}

Ikke så gild som i Deres tid. Den er hugget svært ud.

\section{EKDAL}

Hugget ud? (sagtere og ligesom roed) Det er farlig gerning, det. Det dra'r efter sig. Der er hævn i skogen (s. 81).

Gregers' opplysning om skogens tilstand avføder en bemerkelsesverdig reaksjon hos Ekdal: Han blir «ligesom reed». Og svaret hans er både foruroligende og profetisk. At det «er hævn i skogen», får han på sett og vis rett i, og Ibsen ser ut til å understreke nettopp det når han vender tilbake til dette motivet helt til slutt i stykket. I nest siste scene, etter at Hedvig er død, lar han Ekdal utsi en lignende replikk, attpåtil to ganger: «Skogen hævner.» Det synes som et signal fra dikterens side. Her etableres en alternativ årsakssammenheng gjennom stykket: Hedvigs død er ikke bare en konsekvens av Gregers' kompromissløse sannhetskrav, av Hjalmars selvmedlidenhet, av språklig splittelse eller andre av de mange begrunnelsene som har vært anført helt siden stykket først utkom (jf. f.eks. Hemmer 2003, s. 319-325; Aarseth, u.å.). Selvmordet kan også forstås som skogens hevn for rovdriften som har blitt bedrevet oppe ved verket. Naturen hevner seg på menneskene som utnytter den. ${ }^{6}$

Stykket signaliserer at de to tidligere kompanjongene forholder seg til skogen på fundamentalt ulike måter. I lys av Werles påstand om at det var Ekdal som sto for

6 Mistanken om at Ibsen ønsker å formidle nettopp dette, styrkes av en endring mellom nest siste og siste manuskriptutgave: I nest siste versjon heter det bare at Ekdal uttaler siste del av replikken til Gregers «sagtere», det vil si stillere. I den endelige utgaven er han altså også «ligesom ræed». Stykkets videre forløp viser at redselen er velbegrunnet. 
skogsdriften i forretningssamarbeidet dem imellom, kunne man mistenke at Ekdal bevisst utnyttet skogen for hardt. Men de påfølgende replikkene i dialogen mellom far og sønn Werle i første akt tyder på det motsatte: «Løjtnant Ekdal havde nok ikke selv rede på, hvad han foretog sig», sier Gregers. «Kan gerne være», svarer grossereren. «Men kendsgerningen er nu den, at han blev dømt og jeg frifunden» (s. 37). Ytterligere indikasjoner på at feilen ikke skyldes noe bevisst forsøk på overbeskatning av skogen, kommer fram i den nevnte samtalen mellom Ekdal og Gregers i andre akt. Bare det at Ekdal spør om hvordan skogen «står», signaliserer en form for omsorg for den. Gregers' svar er også megetsigende: Skogen var gild i Ekdals tid, men det er den ikke lenger, på grunn av hogsten. Slik signaliseres det at Ekdal slett ikke har drevet skogen på uforsvarlig vis; tvert imot tyder replikkvekslingen på at driften på Ekdals tid var preget av et respektfullt forhold til den ressursen som skulle utnyttes. Ekdals sosiale og juridiske fall skyldes derfor neppe et bevisst forsøk på å berike seg på naturens (og statens) bekostning. I stedet bunner det $\mathrm{i}$ inkompetanse. Ekdal hadde ikke rede på hva han foretok seg, som Gregers sier, han evner ikke å betrakte naturen på det moderne samfunnets teknokratiske premisser, som i denne sammenheng vil si å betrakte skogen som et objekt som man kan kartlegge og dele opp, og som kan forvaltes med utgangspunkt i streker på et kart, jf. Werles utsagn om «dette uefterrettelige kort». Det Ekdal gjør, og som Ibsen åpner for gjennom ham, er å tilkjenne naturen status som subjekt. Hans stotring og repetisjon tyder på at skogen øver en eller annen form for makt over ham, som han trenger en slurk øl for å overvinne eller håndtere. Han betrakter den som en aktør med selvstendig evne til å handle, og til i hevne. Og det gjør han altså rett i, later stykket til å fortelle. Werle, derimot, frykter ikke skogen og ser ikke ut til å ha noen problemer med å betrakte den utelukkende som et objekt, som materie som har sin eksistensberettigelse i at den kan forvaltes og forbrukes til menneskelige formål. For ham - og for Gregers, som jo jobber for ham - er den en ressurs som kan utnyttes, først og fremst kommersielt. Slik kan man si at de to familiene holder seg med ulike natursyn, og forskjellen kommer konsentrert til uttrykk i dialogen mellom Hedvig og Gregers i tredje akt. «Så; hvad bruger de den da til?» spør han da Hedvig forteller at hun lar Hjalmar og gamle Ekdal få låne villanden så ofte de vil (s. 115). Da har han, sent i foregående akt, stilt et likelydende spørsmål om bingen kaninene ligger i: «Ja; hvad bruger De den til?» (s. 84). Mens spørsmålet er adekvat anvendt på en livløs ting, framstår det som påfallende når det gjelder et kjæledyr; hva bruker man en levende and til? « $\AA$, de steller med den og bygger for den, og sådant noget», svarer Hedvig. Svaret viser at hun, i likhet med sin (ste-)far og (ste-)bestefar, ikke ser på den som en bruksgjenstand; «[f]or henne er anden først og fremst et levende vesen, fremmed og forunderlig», som Edvard Beyer skriver 
(1995, s. 334). Spørsmålet, derimot, avslører at Gregers nettopp ser på villanden som en ting, som får sin verdi vurdert ut fra hva den kan brukes til. Historien om jaktepisoden der villanden skadeskytes, signaliserer at far Werle ser det på samme måte. Her framstår skytingen nærmest som umotivert, som en slags impulshandling: «Han var ude i båd, skønner De; og så skød han på hende», forteller Ekdal (s. 88). Det er neppe for mataukens skyld han skyter, noe som også understrekes av villandens videre skjebne. Snarere dreier det seg om sportsjakt og om en moderne holdning til naturen som sted for rekreasjon og forlystelse, det vil (igjen) si som ressurs for menneskelig bruk og utnyttelse.

Spørsmålet om hvorvidt naturen er et objekt eller et subjekt, er til og med grammatisk kodet inn i stykket, slik Bjarne Berulfsen skriver i en artikkel om pronomenbruken i teksten: «Pronomenet skifter med hun og den alt etter som villanden har individets liv og aktivitet, eller er et vesen som kan være gjenstand for de agerendes objektive iakttagelse og studium» (1963, s. 54). «Det er animelt genus om fuglen betraktet som individ, så å si som familiemedlem, med menneskelige instinkter, drifter og følelser», heter det om tilfellene der Ibsen har benyttet pronomenet «hun». «På den andre siden bruker dikteren den når fuglen ikke lenger fungerer som levende individ, men snarere er å oppfatte som et inventar eller en eiendel» (s. 52). Denne vekslingen er bevisst innskrevet fra dramatikerens side, hevder Berulfsen, og han viser til at Ibsen har gjort endringer i pronomenbruken fra utkastene til den endelige versjonen av stykket. Ifølge Berulfsen er gamle Ekdal den som mest konsekvent betrakter villanden som et individ (s. 55). Hans nettopp siterte beretning om jaktepisoden er illustrerende: «Han var ude i båd, skønner De; og så skød han på hende» (s. 88 , min utheving).

\section{SYMBOL ELLER SYNEKDOKE?}

Nettopp jaktepisoden har blitt brukt som nøkkel til forståelsen av Vildanden. Slik villanden er skadeskutt, er også menneskene i stykket på ulike vis skadd. Villanden blir stykkets sentrale symbol og fungerer som «et bilde på skadeskutte menneskers trang til å klamre seg til illusjonene», som det heter hos Edvard Beyer (1995, s. 334). En slik symbolsk lesning har sågar vært med på å etablere en skillelinje i Ibsens forfatterskap, overgangen fra kritisk realisme til symbolisme (jf. f.eks. Andersen 2012, s. 243-245). Men når spørsmålet gjelder forholdet mellom menneske og natur, representerer en slik lesning et problem. For som Henning $\mathrm{H}$. Wærp antyder i sin økokritiske Hamsun-studie "Hele livet en vandrer i naturen» (2018), vil symbolske tolkninger av omgivelsene i et litterært verk gjerne lede bort fra disse omgivelsene i konkret forstand og i stedet legge til grunn at «omgivelsene 
skal speile noe indre i mennesket» (Wærp 2018, s. 83), nettopp slik den nevnte symbolske fortolkningen av villandmotivet gjør. Ifølge Wærp vil en økokritiker «i større grad vende blikket mot den ytre relasjonen». Om man vil granske denne «ytre relasjonen» i Vildanden, byr synekdoken seg fram som alternativt leseredskap. Forstått som synekdoke blir villanden en pars-pro-toto-representant for en natur som er skadeskutt av Werle, slik også skogen er skadd av samme mann. Og Gregers' replikk blir et tydelig bilde på hans og familien Werles forhold ikke bare til den konkrete villanden, men til naturen i stort. Også Werle selv kan forstås med synekdoken som prisme: I egenskap av å være grosserer er han innsatt som synekdokisk representant for det moderne økonomiske mennesket, som en legemliggjøring av homo economicus. Han er antroposentrismens ansikt, et menneske som ser naturen kun som en potensielt verdifull ressurs, og som har bygget sin rikdom nettopp på utnyttelse av naturressursene. Hans motpart Ekdal, derimot, er stykkets outsider, slik han også framstår som en samfunnets outsider. Han er hensatt til en virksomhet som i merkantil forstand er unyttig, og han finner glede i liksom-naturen familien Ekdal har skapt på loftet. Igjen med synekdoken som leseredskap kan han betraktes som en representant for et forgangent natursyn, der naturen altså oppleves som subjekt og inngir respekt og ærefrykt. Den naturen han står i forbindelse med, er imidlertid forringet eller kanskje tapt, slik liksom-naturen på loftet understreker. Loftet er ikke bare «et tilholdssted for den som har blitt såret av andre» (Hemmer 2003, s. 318), eller et symbol for «en forkrøplet, inautentisk eksistensform» (Aarset 1999, s. 135). Det kan også forstås som en synekdokisk representant for den skadeskutte naturen, understreket blant annet gjennom trærne og dyrene som finnes der, seilduken og fiskegarnet som er brukt som forheng, bøkene med bilder av seilbåter og allusjonen til den flyvende hollender. ${ }^{7}$ Ibsen uthever selv en slik synekdokisk forståelse av loftet som bilde på en degradert natur når han lar Relling karakterisere Ekdal: «De fire-fem fortørkede juletræerne, som han har gemt på, de er for ham det samme, som hele, store, friske Højdalsskogen» (s. 204). Også Ekdal betrakter altså mørkeloftet med synekdoken som prisme, og han avsløres av Relling, som påpeker at det dreier seg om et stykke «natur» som er frarøvet liv og vitalitet gjennom menneskenes domestisering.

Når Berulfsen omtaler beretningen om hvordan villanden kom til familien Ekdal, peker han på et ytterligere prinsipp som utløser bruk av pronomenet «den», nemlig når villandens symbolske kvaliteter trer i forgrunnen (Berulfsen 1963, s. 57ff). Pronomenbruken knytter altså synet på villanden som objekt eller «eiendel» sammen med synet på villanden som symbol: I begge tilfeller blir den en

7 Jf. f.eks. Northam 1971, s. 98, 102; Moi 2006, s. 251. 
«ting» som kan «brukes», enten konkret eller som bilde. Igjen er Gregers den tydeligste representanten for «brukerne», noe Toril Moi observerer når hun i Henrik Ibsen and the Birth of Modernism kritiserer lesninger som forsøker å tilskrive villandmotivet en symbolsk, allegorisk eller metaforisk mening. Dette er å gjenta Gregers' syn på mening, innvender Moi (2006, s. 248ff): For Gregers er villanden et bilde på de falne Ekdalene, "nothing more than a symbol of the degradation of Ekdal and Hialmar», som det heter i John Northams innflytelsesrike Ibsen's Dramatic Method (1971, s. 94f). Og Gregers sammenfører den konkrete og den symbolske bruken av villanden når han oppfordrer Hedvig til å ofre den, som vil si å bruke den konkrete villanden som gjenstand for en symbolsk handling. Igjen reduserer han den - og i tråd med den synekdokiske lesningen også naturen - til et objekt og en ressurs for menneskelig utnyttelse. En bemerkelsesverdig misforståelse i den samtalen der oppfordringen faller, understreker at Hedvig og Gregers skiller seg i synet nettopp på villandens subjekts- eller objektsstatus. Og misforståelsen er nettopp knyttet til pronomenbruken:

\section{HEDVIG}

Jeg vil bé bedstefar skyde vildanden for mig.

\section{GREGERS}

Ja, gør så. Men ikke et ord til Deres mor om noget sligt!

\section{HEDVIG}

Hvorfor ikke det?

\section{GREGERS}

Hun forstår os ikke.

\section{HEDVIG}

Vildanden? Jeg vil prøve det imorgen tidlig (s. 193).

Hedvig tror Gregers’ «hun» viser til villanden, ikke til Gina, som Gregers sikter til. Hun tror det er villanden som ikke forstår. Gregers' objektiverende syn på fuglen forvirrer henne; hun er vant med å betrakte den som et subjekt. 


\section{NATURENS NEMESIS}

Allerede når Ibsen plasserer et barn midt i kryssilden av voksenverdenens konflikter, synes han å trekke veksler på en kontrastvirkning som har opphav i en rousseausk forbindelse mellom barnet og naturen. Og det er flere ting i stykket som plasserer Hedvig i et nærmere forhold til naturen enn de øvrige personene, med Ekdal som mulig unntak. Hennes identifikasjon med selve villanden er velkjent, og i likhet med den ordentlige villanden lever stykkets «lille vildand-mor», som Relling kaller henne, i konstruerte omgivelser. De familiære kulissene som omgir henne, har sitt konkrete motsvar i naturkulissene på loftet, som hun trekkes mot og oppholder seg blant «når det lar sig gøre», slik hun selv erklærer (s. 111). Denne tilhørigheten til loftsrommet knytter henne til skogen, i sin ekdalske surrogatversjon, og til havet ved «at hele rummet og alt sammen heder 'havsens bund'», som hun sier til Gregers. Flere momenter i siste scene synes dessuten å utheve at Hedvig så å si vender tilbake til naturen når hun dør. Både Molviks «Lovet være herren; til jord skal du blive; til jord skal du blive -» (s. 232) og Rellings «Vi skal snakkes ved, når det første græsset er visnet på hendes grav» (s. 233) peker i retning av at hun føres tilbake til eller gjenforenes med naturen etter døden. I samme retning trekker Hjalmars replikk når det går opp for ham hva som har skjedd: «Og jeg, som jog hende fra mig som et dyr! Og så krøb hun forskræmt ind på loftet og døde i kærlighed for mig» (s. 231). Både sammenligningen med et dyr, som underbygges av metaforene «jog» og «krøb», og tilbaketrekningen til kvasi-naturen på loftet knytter henne til naturen og signaliserer at hun vender tilbake til den idet hun begår selvmord. Eller nærmere bestemt: Naturen krever henne tilbake.

Leser man stykket slik, blir Gregers et redskap som skogen iverksetter sin hevn gjennom. Ubevisst og ufrivillig blir han naturens budbringer og den som innfører den dødelige «forgiften» i det ekdalske hjem. Ibsen åpner selv for en slik mulighet i en replikkveksling mellom Gregers og Relling i tredje akt:

RELLING: Om forladelse, - det skulde vel ikke være Dem selv, som bringer stanken med der oppe fra gruberne?

GREGERS: Det kunde ligne Dem at kalde for stank, hvad jeg bringer ind i huset (s. 138).

Gregers' første replikk idet han gjør sin entré i dette huset, bærer også bud om hans rolle som uforvarende dødbringer: «Om forladelse -» sier han idet Gina åpner døren for ham (s. 72). Funksjonen som budbringer utheves videre av hans første replikk i dialogen med Ekdal: «Jeg vilde bare hilse Dem fra de gamle jagttomterne, 
løjtnant Ekdal» (s. 79). At han kommer direkte fra Højdalsverket til Werles selskap i første akt, altså til stykkets synekdokiske representant for menneskelig økonomisk kultur, understreker det samme, likeledes hans metaforiske parallellisering av seg selv med hunden i fortellingen om villanden: Han er den som bringer (den synekdokiske representanten for) naturen tilbake til mennesket. ${ }^{8}$

Naturens krav om Hedvig som offer kan også forstås i evolusjonært perspektiv: Når Hedvig dør, dør også Werle-slekten ut. Med gammeltestamentlig - eller ny biologisk - ubarmhjertighet utrydder naturen en familie som har forgrepet seg mot den eller syndet mot den. Naturen i Vildanden inntar en rolle lignende den skjebnen har i antikkens drama, som en instans som bestemmer vilkårene for menneskets liv, og som straffer den som setter seg opp mot disse vilkårene. Forestillingen om en slik dømmende skjebneinstans er klart til stede i stykket, og et element av menneskelig hybris er heller ikke vanskelig å få øye på. Det mer enn antydes at Werle går skjebnen i næringen ved å ikle seg rollen som skjebneinstans for andre mennesker, for eksempel når Gregers i første akt sier til Hjalmar: «Far har nok næsten været som et slags forsyn for dig, han» (s. 25). Men gjennom sitt opplysningsprosjekt ikler også Gregers seg rollen som forsyn for både Hjalmar, Gina og Hedvig, selv om han muligens ikke ser det selv. Tanken om at det straffer seg å opptre som forvalter av andres liv, introduseres i klartekst av Hjalmar i fjerde akt: Etter først å ha klaget over at det framstår «som om der slet ingen retfærdig verdensstyrelse var til», modererer han oppfatningen når han tenker på Werles blindhet: «Men på den anden side er det jo rigtignok som om jeg øjner skæbnens regulerende finger alligevel. Han blir jo blind.» (s. 178) Og umiddelbart etterpå: «Det er utvilsomt. Vi bør ikke tvile på det $\mathrm{i}$ al fald; for just i dette faktum ligger den retfærdige gengældelse. Han har i sin tid forblindet en troskyldig medskabning -» (s. 179). Sammenhengen som signaliseres, er denne: Familien som opptrer som forsyn for andre, settes på plass av det virkelige forsynet, som opptrer i biologisk drakt når det straffer først ved hjelp av en arvelig blindhet, siden ved å kreve Hedvig som offer. I begge tilfeller blir hun offer for sin fars og sin halvbrors synder. ${ }^{9}$

8 At han ikke selv er klar over hva han gjør, er helt i tråd med hamartia-begrepets aristoteliske opphav og med den rollen stykket muligens tilbyr ham som tragisk helt, selv om denne nok må forstås ironisk (jf. f.eks. Aarseth 1999, s. 144).

9 Forbindelsen mellom blindhet og (guddommelig) rettferdighet er jo også konvensjonalisert gjennom den romerske gudinnen Justitia, selv om blindheten da vedkommer den dømmende, ikke den dømte. 


\section{ØKONOMIENS SPRÅK}

Vildanden er ikke blant stykkene Atle Kittang diskuterer inngående i Ibsens heroisme, men det skillet han etablerer mellom «ontisk skuld» og «ontologisk skuld», virker produktivt også her. For uklarheten om hvem som straffes, og hvem som har syndet, plasserer dette skillet i selve kjernen av stykket: Skriver skylden - og hevnen - seg fra «den moralske samanhengen mellom handling og skuld», eller kan den tilbakeføres til en «medfødd og nedervd arvesynd» (Kittang 2002, s. 179)? Er det individer som straffes for sine handlinger, eller er det mennesket som straffes for sin kollektive synd? Den straffen som tilkommer Werle-familien i Vildanden, kan forstås som en straff for at far og sønn plasserer seg i rollen som herre og hersker både overfor sine medmennesker og overfor naturen; de utnytter både sine naturlige og sine sosiale omgivelser i egen vinnings hensikt. Igjen med synekdoken som prisme kan vi si at straffen som rammer dem, er en straff som tilkommer det moderne økonomiske, nyttemaksimerende mennesket. Grossererens synekdokiske rolle i denne sammenhengen er allerede omtalt, men også Gregers er intellektuelt innfanget i økonomiens logikk, og i dens språk. Gregers er en (forfeilet) idealist, det er klart, men i sin språkbruk avslører han at han er en idealist som er oppfostret av en materialist. Stykket mer enn antyder at både far og sønn Werle forstår alt i sine omgivelser - både natur og mennesker - innenfor rammene av økonomiens nytteorienterte rasjonalitet. Jeg har nevnt Gregers' spørsmål om hva villanden kan brukes til. Men han anvender den samme tenkemåten og det samme språket i forståelsen av faren: «Nu skønner jeg, hvad det er, du vil bruge mig til», sier han til grossereren i første akt (s. 46). «Bruge dig til? Hvad er dog det for et udtryk!» svarer Werle. Men om uttrykket vekker anstøt, viser hans manipulasjon av Hjalmar at tanken om å bruke andre mennesker for å oppnå egen fordel ikke er ham fremmed. Det er den ikke for Gregers heller. Med begrepet «den ideale fordring» demonstrerer han at også han forstår mellommenneskelige - og metafysiske - størrelser innenfor økonomiske rammer. Med støtte i kognitiv metaforteori kunne vi si at metaforen avslører en grunnleggende tankefigur, et «metaforisk begrep» (Lakoff \& Johnson, 2003) eller et «tankekonsept» (Askeland \& Agdestein, 2019) hos Gregers. Det kunne lyde: Idealer er betalingsmidler. Den økonomiske metaforikken bygges ut i replikkvekslingen der selve metaforen introduseres, samtidig som Hjalmars manglende forståelse understreker at det nettopp dreier seg om metaforikk, altså om overføring av et innhold fra ett område (økonomiens) til et annet (metafysikkens eller etikkens):

\section{RELLING}

Og fik De så inkasseret den fordringen, De gik omkring med? 


\section{GREGERS}

Fordringen? (forstår ham) Nå så.

HJALMAR

Har $d u$ inkasseret fordringer, Gregers?

\section{GREGERS}

Å snak.

\section{RELLING}

Jo såmænd har han så; han gik omkring i alle husmandshytterne og præsenterte noget, som han kaldte «den ideale fordring».

\section{GREGERS}

Jeg var ung dengang.

\section{RELLING}

De har ret i det; De var svært ung. Og den ideale fordringen - den fik De da aldrig honoreret så længe jeg var der oppe.

\section{GREGERS}

Ikke siden heller.

\section{RELLING}

Nå, så er De vel ble’t så klog at slå lidt af på beløbet da, kan jeg tænke.

\section{GREGERS}

Aldrig når jeg står foran et ægte, virkeligt menneske.

\section{HJALMAR}

Nej, det synes jeg jo er ganske rimeligt. - Lidt smør, Gina (s. 133f).

Gregers' avsluttende svar viser at han har holdt fast ved sin oppfatning om at sannhet og idealer kan behandles på samme måte som man behandler pengekrav, og at han ser det som sin oppgave å fungere som «inkassator», som Relling sier det. Men idealismen er bare tilsynelatende, for det å påta seg denne rollen er en investering som skal sikre ham selv en avkastning, slik det tydelig går fram når han omtaler 
prosjektet med å opplyse Hjalmar. Det gir ham «endelig én gang en opgave at leve for», som han sier i første akt (s. 48). ${ }^{10}$

Det er derfor lett å være enig i Bjørn Hemmers påstand om at «også en språklig og begrepsmessig forvirring fører til katastrofen i det ekdalske hus» (2003, s. 318, jf. også Northam, 1971, s. 98-106; Moi, 2006, s. 248-268). Som Hemmer også påpeker, kommer spørsmålet om språklig betydning til syne både gjennom Relling og Gregers' oppfatning av ordene «idealer» og «løgne» som henholdsvis synonymer og antonymer, gjennom Hjalmars tomme resirkulering av Gregers' uttrykksmåter og gjennom Hedvigs fornemmelse av en skjult betydning i Gregers' utsagn. «Det er et dominerende trekk ved dramaet at Gregers påtvinger den ekdalske familien et språk og en begrepsverden som er den helt fremmed», skriver han og uthever Gregers' «metaforiske tale» (2003, s. 318). I herværende sammenheng kan påstanden utvides. Til den språklige og begrepsmessige forvirringen bidrar også Gregers' økonomiske begrepsapparat og ideen om at menneskenes forhold til hverandre og til naturen kan fanges inn i økonomiens vokabular og logikk. En slik forestilling er selve foranledningen til den språklige misforståelsen som utløser tragedien. Som mange har påpekt, skyldes Hedvigs selvmord at hun misforstår Hjalmars replikk: «Hedvig, er du villig til at gi’ slip på livet for mig?» (s. 224). Hjalmars uttrykk er nokså åpenbart ment metaforisk, ikke bokstavelig. Det knytter an til den foregående replikken i samtalen mellom ham og Gregers om det livet han tror familien Werle vil tilby henne: «Dersom de andre kom, de, med de bugnende hænder, og råbte til barnet: gå ifra ham; hos os har du livet ivente -» (s. 224). Her blir begrepet «livet» brukt metaforisk om en tilværelse i rikdom, luksus, overflod eller lignende, «en tilværelse blant de rike», som Asbjørn Aarseth skriver i Ibsens samtidsskuespill. En studie i glasskapets dramaturgi (1999, s. 143). Vi skimter Gregers' metaforiske talemåter bak Hjalmars «lånte, retoriske gevanter» (Hemmer 2003, s. 321). Men vel så påfallende er det imidlertid at Hjalmar overtar Gregers’ økonomisk inspirerte tenkemåte: Han tror at et slikt livsvalg som Hedvig eventuelt kunne komme til å bli stilt overfor, vil avgjøres av økonomiske eller materielle avveininger, og han forskutterer Hedvigs valg ut fra forutsetningen at hun skal opptre som en rasjonelt kalkulerende aktør, det vil si som et økonomisk menneske, med materiell gevinst som øverste mål. «[K]anskje Hedvig aldrig har holdt rigtig ærligt af mig», sier han like før (s. 222) og avslører den nærmest absurde mistanken at Hedvig hele livet skal ha drevet et maskespill overfor ham i påvente av at grosserer Werle skal tilby henne et materielt rikere liv: «Nu føler jeg det så nagende

10 Som Aarseth bemerker, stammer den ideale fordringen dessuten ikke «fra noe åpent og friskt høyfjellsliv», men fra «noe innelukket om mørkt, nemlig gruvene» (1999, s. 139). Slik understrekes forbindelsen mellom industriell og idealistisk kapitalisme, kunne man si. 
sikkert, - den fattige fotograf oppe i loftslejligheden har aldrig været noget helt og fuldt for hende. Hun har bare så listelig sørget for at stå på en god fod med ham så længe til tiden kom.» Når Gregers prøver å snakke ham til rette, griper han til Gregers' egen metafor: «Hå-hå, du stoler for stærkt på den ideale fordring, min gode Gregers!» Da har han akkurat sagt om Gina at hun «mangler [...] så aldeles sans for den ideale side af forviklingerne.» Hjalmar forstår ikke Gregers’ idealistiske prosjekt, og han forstår heller ikke hans ideal-metaforikk, slik den omtalte samtalen mellom Gregers, Relling og Hjalmar i fjerde akt tydeliggjør. Dermed sitter han igjen bare med metaforens økonomiske logikk. Det straffer seg.

\section{«DEN STORE GÅDE» - NATUR, MATERIALISME OG MYSTIKK}

Bogen har jeg læst med stor interesse, så meget mere, som jeg i længere tid har beskæftiget mig adskilligt med de herhen hørende emner. Men intet af de resultater, videnskaben hidtil synes at være kommen til, har kunnet tilfredsstille mig. Jeg har derfor dannet mig min egen personlige og uafhængige naturanskuelse. Jeg tror at både teologerne og naturforskerne stikker dybt i ensidighed. «Naturen» er ikke noget så materielt, som mange synes at ville gøre den til. Men hvad der stikker bagved, - det er den store gåde, den foreløbige hemmelighed.

Dette skriver Ibsen i et brev til medisineren Ferdinand Lochmann 17. mai 1888. Boken han sikter til, er Lochmanns Den nyere Naturanskuelse fra samme år, som han må ha fått tilsendt fra forfatteren på senvinteren eller våren og ikke ventet lenge med å lese. Her går Lochmann i rette med det han kaller «de dogmatiske Darwinister», som han med beklagelse også finner blant forfatterne, ikke minst i bohembevegelsen (Lochmann 1888, s. 42f). Ifølge Lochmann er den vitenskapelige materialismen passé: «Tanken om en Enhed og en Sammenhæng af alle Livsformer er det egentlige Midtpunkt for den moderne Naturanskuelse» (s. 12). Han støtter seg blant annet på botanikeren F. R. Cohn: «Han erkjender aabent, at de mekaniske og fysiske Kræfter umulig kan forklare Livsytringerne, og han gaar tilbage til Aristoteles' Opfatning, at alt Liv er af psykisk Art, og at Livets Væsen maa søges i det sjælelige; ikke blot Dyret, men ogsaa Planterne har en Sjæl» (s. 16f).

Lochmanns utgangspunkt er kristent og sterkt konservativt, og det er neppe grunn til å trekke politiske paralleller mellom Lochmann og Ibsen. Tvert imot identifiserer Ibsen-biograf Ivo de Figueiredo en politisk dreining i radikal lei hos Ibsen rundt midten av 1880-tallet (2019, s. 464f). Men han påpeker også at Ibsen 
samtidig - og samtidig som Vildanden ble klargjort for utgivelse - fattet interesse for spiritisme (s. 467). ${ }^{11}$ Det er altså grunn til å tro at tanken om at naturen kan betraktes som mer enn bare materie, og at omgivelsene rommer ukjente krefter som virker inn på menneskene, neppe var fjern for Ibsen anno 1884, slik den heller ikke var det i 1888, som brevsitatet ovenfor indikerer. I et forarbeid til Vildanden utstyrer han også naturen med en slags kraft over mennesket når han noterer: «Hedvigs dragning mod havet.» (NBO Ms. $8^{\circ} 1944^{12}$ ). I det hele tatt er spørsmålet om forholdet mellom menneske og natur et problemfelt som preget nær sagt alle sider av samfunnet gjennom andre halvdel av 1800-tallet, med spørsmålet om menneskets avstamning og utvikling som kjernepunkt. Det er et spørsmål med eksistensielle implikasjoner, slik Lochmann signaliserer når han skriver: «Det vanskeligste Problem for den nyere Naturanskuelse er aabenbart Forstaaelsen og Erkjendelsen af Menneskets dobbelte Natur, af dets Forbindelse med den øvrige Skabning og samtidig dets Uafhængighed og absolutte Forskjel» (1888, s. 55). Biologien - og Darwin især - gjorde det påtrengende å ta stilling til om eller hvordan mennesket er natur. Det er neppe tilfeldig at Ibsen utstyrer sitt mørkeloft med de samme dyrene som Darwin omtaler når han skriver om husdyrforedling i On the Origin of Species (jf. Aarseth 1999, s. 127f).

Motsetningen mellom vitenskapelig materialisme på den ene siden og mystisisme på den andre har en parallell i Vildanden $\mathrm{i}$ form av den antitesen Northam har påvist «between brightness and green obscurity» (1971, s. 86). Det grønne er uklart og står som en motsats til rasjonalitetens skarpe lys, som vi kjenner fra den veletablerte metaforikken som knytter lys til kunnskap. Lysets skadevirkninger er konkret uthevet i stykket gjennom koblingen til blindhet: «De skal ikke gå længer derinde og stirre på alle lysene; De har ikke godt af det», sier fru Sørby til grossereren (s. 25). At belysning og opplysning i stykket er to sider av samme sak, og at denne saken kan være skadelig, tydeliggjøres når vi hører at Hedvig ikke får gå på skole fordi Hjalmar frykter at hun skal «fordærve øjnene», som hun sier til Gregers (s. 111). For mye opplysning - i konkret og overført betydning - gjør blind. Som Tore Rem og Narve Fulsås påpeker, betraktet Ibsen selv Vildanden som «a departure from social art and from the unqualified blessings of exposing the truth» (2018, s. 126).

Antitesen Northam påpeker, er tydelig skrevet inn i stykket også i framstillingen av familien Werles og familien Ekdals hjem. Sceneanvisningene som beskriver de to stedene dramaet utspiller seg på, rommer det som er både en parallell og en kon-

11 Ibsen sendte sitt endelige manus til sin forlegger 2. september. Samme måned ble han introdusert for en frøken Schirmer, som bedrev spiritisme (de Figueiredo 2019, s. 247). 
trast. Hos begge ser vi i forgrunnen et rom med skjermet belysning, og bak disse rommene er det et annet rom, atskilt fra det fremre av fløydører og forheng. Men der dette bakre rommet hos grossereren er «stærkt oplyst af lamper og armstager», er dørene hos Ekdal stengt ved begynnelsen av andre akt. Det indre er skjult. Og når dørene åpnes, «ses et stort, langstrakt, uregelmæssigt loftsrum med krinkelkroge og et par fritstående skorstenspiber. Der er tag-glugger, hvorigennem et klart månelys falder ind over enkelte dele af det store rum; andre ligger i dyb skygge» (s. 83). Det bakenforliggende, med alt det det representerer, får forbli uoversiktlig og delvis skjult. Hos grossereren hersker full opplysning.

Slik sidestilles det (overdrevent) belyste og opplyste med en økonomisk og vitenskapelig materialisme og med en oppfatning av menneskets «Uafhængighed og absolutte Forskjel» fra naturen. For Ekdalene er det annerledes. Hedvig, Hjalmar og Ekdal oppholder seg i det uklare, $\mathrm{i}$ «the dim green mystery», som Northam skriver. De tre er de eneste i stykket som «are clearly connected to this mysterious world» (1971, s. 94), og dermed også «med den øvrige Skabning». Til grunn for den misforståelsen som fører til Hedvigs tragiske skjebne, ligger det en identifikasjon med villanden, det vil si en «Forbindelse» som underminerer et klart skille mellom henne selv og fuglen. For henne har hun og villanden samme moralske status, de er begge både subjekter (jf. pronomenbruken) og objekter (jf. offerhandlingen). Faktisk avslører Gregers selv en forståelse for en slik intim forbindelse mellom mennesket og naturen når han i andre akt spør hvordan Ekdal - «slig en friluftsmand» - kan leve «midt i en kvalm by», atskilt fra «alt det, som Deres sind er vokset sammen med? Denne svale strygende luftningen, dette fri livet i skog og på vidder, mellem dyr og fugl -?» (s. 81).

Slik kan man si at Vildanden kan leses som en refleksjon omkring hva som kan skje når mennesket setter seg ut over naturen, eller nekter å vedkjenne seg sin forbindelse med, sin tilhørighet til og sitt ansvar overfor den. På flerfoldige vis leder et teknokratisk, materialistisk og økonomisk-rasjonelt menneske- og natursyn til ulykke for begge familiene i stykket. Kanskje skyldes Ekdals rolle som stykkets «human wreck» (Northam 1971, s. 93) ikke bare at han er sosialt degradert, men også at han er fordrevet fra det man kunne kalle hans naturlige «habitat», slik Gregers også antyder: Atskilt fra eller hevet over naturen går mennesket til grunne, straffet av en natur som inntar skjebnens rolle. Slik kan stykket leses som en advarsel til det moderne mennesket, egnet til å skape frykt og vekke «bevisstheten om en truende ulykke som vil kunne ramme oss selv», som det heter når Elke PlatzWaury utlegger det aristoteliske katarsis-begrepet i sin innføringsbok Drama og teater (1992, s. 124). 
En ytterligere grunn til å lese Vildanden som en refleksjon omkring det moderne menneskets forhold til naturen finnes i Welhavens «Søfuglen», som er allment anerkjent som det intertekstuelle forelegget for Ibsens villand-motiv. Diktet ble først trykket i avisen Den Constitutionelle 12. august 1836, der det avslutter den siste av tre artikler i serien «Skizzer fra Frankrig», som bærer tittelen «Literatur. La Morgue». Artikkelen er en refleksjon over livets og dødens plass og verdi i det moderne og urbane samfunnet; den gir, med Slagstads ord, «innsikt i den moderne kalkylens pris» (2001, s. 87). Ifølge Slagstad delte Welhaven den estetiske romantikkens motstand mot «opplysningsrasjonalismen og dens naturbeherskende moderniseringsprosjekt». Et kritisk blikk på menneskets økonomiske og teknokratiske syn på naturen ligger dermed både para- og intertekstuelt innskrevet allerede i stykkets tittel. Dette understøtter den oppfatningen at også Vildanden målbærer en slik refleksjon over prisen ved et moderne teknokratisk og kalkulerende (menneske- og) natursyn. «Leiegårdsloftet i Christiania som likhuset i Paris - begge pekte de mot modernitetens nattside», skriver Slagstad (2001, s. 87).

Dertil kommer referansen til sagnet om Den flyvende hollender. Det forteller om kapteinen som forbanner Gud og dømmes til evig seilas. Med røtter som trolig går tilbake til Det nederlandske ostindiske kompani, står både skikkelsen og myten historisk i forbindelse med moderne handelsvirksomhet. Den er, skriver Eivind Tjønneland i Ibsen og moderniteten, «en myte på modernitetens livsfølelse» (1993, s. 21), og påkallelsen av den i Vildanden bidrar til å trekke oppmerksomheten mot betydningen av moderne handelsvirksomhet. ${ }^{13} \mathrm{I}$ «The Rime of the Ancient Mariner», Samuel Taylor Coleridges berømte diktversjon av myten, består sjømannens overgrep i å skyte en fugl, en albatross. Parallellen til Werle er åpenbar: Naturen tar skade av menneskets økonomisk motiverte hensynsløshet. Og den tar hevn.

Samtidig, og på Ibsens sedvanlige ikke-entydige maner, later stykket til å motsette seg en enkel økologisk moral. Riktignok ble Ibsens dramaer til innenfor det Aarseth kaller «en romantisk, natur- og frihetsdyrkende kontekst» (1999, s. 135),

13 Som Tjønneland også påpeker (1993, s. 26-28), kan ordet «hollender» for Ibsen og hans samtidige ha konnotert «historiker», en betydning som skriver seg fra hollender-kretsen som Ibsen også selv tilhørte på 1850- og 60-tallet, med Paul Botten-Hansen som den sentrale skikkelsen, og med Aasmund Vinje, Ludvig Daae og Michael Birkeland som viktige figurer. Kanskje er dette å lese som en kritikk av en moderne, fortørket og antikvarisk historieforskning som ikke lar fortiden gripe inn i nåtiden, slik Tjønneland skriver. Det munner ut i en modernitetskritikk: «Skillet mellom [...] det tidløse og det som er i tiden, ødelegger også syntesen mellom fortid og nåtid. Historien stenges inne på mørkeloftet og befinner seg i det tidløse», skriver han (s. 28). At denne hollenderen eller historikeren har reist og bare etterlatt seg en håndfull remedier, understreker det moderne menneskets distanse til fortiden: Den eksisterer bare for oss i form av historiske levninger, og når historikeren er borte, må vi gjøre mening av disse uten kyndig hjelp. 
og i allusjonen til Darwin finner han «en implisitt moralfilosofisk evaluering av overgangen fra vill til tam tilstand, fra naturlig til kunstig eksistens», hvor «det ville, naturlige og frie [blir] opplevd som autentisk liv, mens det tamme og ufrie blir stemplet som annenrangs» $(1999,128)$. Likevel er det neppe slik at stykket målbærer noen «straightforward tributes» til et enkelt liv i pakt med naturen, som Dean Krouk bemerker i sin diskusjon av «Forest Fiction»: «[... ] Vildanden is more complicated: not a sincere tribute to the virtues of natural life as woodcutters, but rather an echo of its ironic and skeptical presentation of the romantic vision» (Krouk, 2014, s. 143). Det ironiske eller skeptiske i framstillingen av denne romantiske naturvisjonen underbygges av at Ekdal unektelig er tegnet med en strek som grenser til karikaturen. Skillet mellom økosentrisk respekt og antroposentrisk utnyttelse av naturen utydeliggjøres også både av hans tidligere bjørnejeger-karriere og av hans huslige kaninjakt i stykkets nåtid. Når han skryter av å ha skutt hele ni bjørner, skryter han av å ha opptrådt i tråd med intensjonen bak Lov om Udryddelse af Rovdyr og om Fredning af andet Vildt av 1845, som hadde som mål à utrydde de store rovdyrene fra norsk natur for å verne andre dyr: elg, hjort, villrein, skogsfugl og ikke minst husdyr, det vil si dyr som var økonomisk mer gagnlige enn rovdyrene. Loven økte skuddpremien på noen dyr, som bjørn og ulv, og innførte den for andre, som gaupe, jerv og flere rovfugler. Det underliggende natursynet er antroposentrisk i den grad at det (selv) i dag framstår som oppsiktsvekkende: «Hvis en arts nytteverdi ansees som lavere enn skaden den gjør, mener han den bør utryddes. Hvis artens nytteverdi derimot overstiger skadevirkningene, bør den få fortsette å eksistere i landet», skriver idéhistoriker Karl Martin Richardsen om argumentasjonen til naturforskeren Halvor Heyerdahl Rasch, arkitekten bak loven (Richardsen, 2014, s. 12). I tillegg til å verne om de økonomisk nyttige dyre- og fugleartene skulle jakten ifølge Rasch også tjene som militær øvelse (Richardsen, 2014, s. 7f), noe som forklarer forbindelsen mellom bjørnejegeren og løytnanten Ekdal. Kanskje kan man også si at Hedvigs skjebne illustrerer hvor galt det kan gå når man ikke opprettholder et klart skille mellom menneske og natur, og i stedet henfaller til en relativisme der mennesket ikke prinsipielt er hevet over andre livsformer.

En inngang som kan romme også denne latente ironien, finnes kanskje i Fulsås og Rems påstand om at Vildanden kan leses som uttrykk for en vending mot «the social unconscious» hos Ibsen. I motsetning til Nora Helmer og Helene Alving er ikke i Hedvig i stand til å forstå vilkårene hun lever under og betingelsene som settes opp for henne (2018, s. 126f). Lest i økokritisk lys, og med synekdoken som leseredskap, kan Hedvig da forstås som en synekdokisk representant for en menneskehet som forsøker å kontrollere og optimalisere sine egne livsbetingelser 
med utgangspunkt i en mangelfull forståelse av de samme betingelsene. I forsøket stilles både hun og de andre overfor noe som unndrar seg bevisst erkjennelse, det vil si noe obskurt, som altså i Vildanden nettopp er knyttet til det grønne og til naturen, slik Northam påpeker. Både individene selv, forholdet dem imellom og forholdet mellom menneske og natur blir skadelidende når mennesket nekter å se naturen - både i dem og utenfor dem - som et ukontrollerbart subjekt, og i stedet ser - eller, for Hedvigs og Ekdals del, tvinges til å se - seg selv og sin omverden kun i teknokratiets, økonomiens eller materialismens belysning, det vil si som et presumptivt kontrollerbart - og potensielt utnyttbart - objekt. I en økokritisk lesning finner vi her et tematisk sentrum i stykket: Mens det vil være anakronistisk og etter min mening hermeneutisk forkjært å lese inn i det et budskap om miljøvern $\mathrm{i}$ moderne forstand, synes dramaet likevel å framheve en idé om respekt for naturens obskuritet og integritet. Det målbærer, slik jeg leser det, en anerkjennelse av at naturen rommer noe mennesket ikke kjenner eller kontrollerer, at det er noe som «stikker bagved», som det heter i Ibsens brev til Lochmann.

\section{FORTID, NÅTID OG FRAMTID - KORT OPPSUMMERING}

For avslutningsvis å løfte blikket vil jeg anføre to momenter ved denne lesningen som kanskje bærer i seg større muligheter for litteraturdidaktikken enn dem som gjelder dette verket spesifikt. For det første kan man i forlengelsen av Wærps påstand, som jeg gjenga ovenfor, diskutere om symbolet generelt er mindre egnet til å granske «the relationship between literature and the physical environment», som det heter i en ofte sitert avgrensning av begrepet økokritikk (Glotfelty \& Fromm, 1996, s. xviii). Kan hende er synekdoken, som ofte anses å bygge på en nærhetsrelasjon, en mer «jordnær» trope enn symbolet, og kanskje er synekdokiske lesninger mer egnet enn symbolorienterte til å synliggjøre hvordan tekster lar (eller ikke lar) våre omgivelser representeres i litteraturen? Det er et spørsmål som etter min mening fortjener å utprøves videre i undervisning og i forskning. For det andre kan man spørre om slike grønne lesninger som jeg her har forsøkt å eksemplifisere, rommer i seg nye legitimeringsmuligheter for litteraturundervisningen generelt og litteraturhistorieundervisningen spesielt. Mange har påpekt behovet for nye og oppdaterte legitimeringer for skolens litteraturarbeid (se f.eks. Andersen, 2011; Aase \& Kaspersen, 2012 eller Penne, 2013), og kanskje kan en grønn tilnærming til litteraturen og litteraturhistorien både åpne for en autentisk utforskning av litteraturhistorien, siden dette fremdeles for en stor del er upløyd mark i litteraturforskningen, og sette både eldre og nyere litteratur inn i rammer - 
politiske, teknologiske, eksistensielle - som føles relevante og akutte for dagens skoleelever.

Allusjonen til «Søfuglen» er allerede nevnt og kommentert, men én ting gjenstår å si. Den tilfører nemlig også en viktig kontrast: For der bølgen i «Søfuglen» «sletter ud dens spor», som det heter i fjerde strofe, og altså skjuler eller fjerner konsekvensene av det jegeren gjør, forsvinner ikke sporene etter menneskenes ugjerning i Vildanden. Tvert imot: Villanden vender tilbake, slik naturen også kommer tilbake for å hevne seg. Slik presenterer Ibsen her en ny variant av et antikt dramatisk motiv som han i 1884 allerede har turnert i mange forskjellige former: mennesket som innhentes av sin fortid. Men i Vildanden er det ikke bare ett individ eller én familie, men selve det moderne mennesket som innhentes og straffes. Det moderne mennesket stilles overfor - og til ansvar for - en besjelet og hevnende ikke-menneskelig natur. Og her viser stykket seg skremmende aktuelt. «Selv om det er mye komikk i Vildanden, er det ikke vanskelig å se at dramaets hovedperspektiv fanger inn barnets tragedie», skriver Hemmer (2003, s. 315), en påstand det er lett å stille seg bak. Men tydeligere enn i 1884 rommer denne tragedien i dag et ytterligere lag, som på tilsvarende vis plasserer barnet som uskyldig offer for det moderne menneskets selviske misgjerninger: I vår tid er det også barnets tragedie at det arver en jord som ser ut til å tilby langt dårligere vilkår for å leve et trygt og godt liv for de kommende generasjonene enn den har kunnet tilby de foregående.

\section{LITTERATUR}

Andersen, P. T. (2011). Hva skal vi med skjønnlitteraturen i skolen? Norskloeraren 35(2), 15-22.

Andersen, P. T. (2012). Norsk litteraturhistorie (2. utg.). Oslo: Universitetsforlaget.

Askeland, N. og Agdestein, M. (2019). Metaforer. Hva, hvor og hvorfor? Oslo: Universitetsforlaget.

Berulfsen, B. (1963). «Vildanden» - hun eller den? Maal og minne 1963, 1-2, 47-59.

Beyer, E. (1995). Fra Ibsen til Garborg. Bind 3 i E. Beyer (red.), Norges litteraturhistorie (4. utg.). Oslo: Cappelen.

Figueiredo, I. de (2019). Henrik Ibsen. Mennesket og masken. Oslo: Aschehoug.

Fulsas, N. \& Rem, T. (2018). Ibsen, Scandinavia and the making of a world drama. Cambridge: Cambridge University Press.

Glotfelty, C. \& Fromm, H. (red.) (1996). The Ecocriticism Reader. Landmarks in Literary Ecology. Athens, Ga.: University of Georgia Press.

Hemmer, B. (2003). Ibsen. Kunstnerens vei. Bergen: Vigmostad Bjørke.

Hodne, F. \& Grytten, O. H. (2000). Norsk økonomi i det nittende århundre. Bergen: Fagbokforlaget.

Ibsen, H. (2009). Henrik Ibsens skrifter 8: Vildanden; Hvide heste; Rosmersholm; Fruen fra havet. Oslo: Universitetet i Oslo. 
Kittang, A. (2002). Ibsens heroisme. Frå Brand til Når vi døde vågner. Oslo: Gyldendal.

Krouk, D. (2014). «Forest Fictions: Thomas Bernhard's Holzfällen and Henrik Ibsen's Vildanden». Scandinavian Studies, 86(2), 133-147. https://doi.org/10.5406/scanstud.86.2.0133

Lakoff, G. \& Johnson, M. (2003). Hverdagslivets metaforer. Fornuft, følelser og menneskehjernen (M. Hidle, overs.). Oslo: Pax.

Lochmann, F. (1888). Den nyere Naturanskuelse. Christiania: Aschehoug.

Moi, T. (2006). Henrik Ibsen and the Birth of Modernism. Art, Theater, Philosophy. Oxford: Oxford University Press.

Northam, J. (1971). Ibsen's Dramatic Method. A Study of the Prose Dramas (2. utg.). Oslo: Universitetsforlaget.

Penne, S. (2013). «Skjønnlitteraturen i skolen i et literacy-perspektiv.» I A. Veum \& K. Skovholt (red.), Literacy i loeringskontekster (s. 42-54). Oslo: Cappelen Damm akademisk.

Platz-Waury, E. (1992). Drama og teater. En innføring. (O. I. Langholm, overs.). Oslo: Ad Notam forlag.

Richardsen, K. M. (2014). «Rovdyrenes Ødelæggelse». Heimen, 51(1), 3-19. https://doi.org/ 10.18261/ISSN1894-3195-2014-01-02

Slagstad, R. (2001). De nasjonale strateger. Oslo: Pax.

Tjønneland, E. (1993). Ibsen og moderniteten. Oslo: Spartacus.

Wærp, H. H. (2018). «Hele livet en vandrer i naturen». Økokritiske lesninger i Knut Hamsuns forfatterskap. Stamsund: Orkana akademisk.

Aarseth, Asbjørn. (1999). Ibsens samtidsskuespill. En studie i glasskapets dramaturgi. Oslo: Universitetsforlaget.

Aarseth, Asbjørn. (u.å). Innledning til Vildanden. Hentet fra https://www.ibsen.uio.no/DRINNL_Vi|intro_publication.xhtml

Aase, L. \& Kaspersen, P. (2012). «Den nordiske skolen - fins den?» I Norskloeraren 35(4), 35-44. 